\title{
Preventing crime in cooperation with the mental health care profession
}

\author{
Joke M. Harte ${ }^{1,2}$
}

Published online: 24 October 2015

C The Author(s) 2015. This article is published with open access at Springerlink.com

\begin{abstract}
Although major mental disorders do not have a central position in many criminological theories, there seems to be an evident relationship between these disorders and criminal behavior. In daily practice police officers and mental health care workers work jointly to prevent nuisance and crime and to keep the city livable. Examining the situations where the criminal justice system and mental health institutes are jointly involved to prevent crime, some pitfalls emerge that seem to threaten successful cooperation. There appear to be unrealistic expectations of the possibility to reduce the risk of reoffending by means of treatment and of the possibility to predict which offender poses a risk to society. Another complexity is the fact that both parties work from different backgrounds and pursue different goals. The way society and the criminal justice system deal with persons who are assumed to be a risk to the community because of a mental disorder demands a further investigation from a criminological perspective.
\end{abstract}

In August 2007, the Amsterdam local news reports that this morning the Damsquare had been closed by the police for some hours. At a height of $30 \mathrm{~m}$, a man had appeared to be sitting on the head of a statue of the Royal Palace, while playing his harmonica. With the help of a psychiatrist, a police arrest team gets the man down and hands him over to a psychiatric hospital.

On March 26, 2009, the Amsterdam police say they have arrested a man suspected of killing a 69 years old man, working as a supervisor in the playground of a primary school, 2 days earlier. The victim was stabbed to death with a knife amidst playing

Joke M. Harte

j.harte@vu.nl

1 VU School of Criminology, Department of Criminal Law and Criminology, Faculty of Law, VU University Amsterdam, De Boelelaan 1105, 1081 HV Amsterdam, The Netherlands

2 Netherlands Institute for the Study of Crime and Law Enforcement (NSCR), PO Box 71304, 1008 BH Amsterdam, The Netherlands 
children. Further investigation reveals that there is no connection between the offender and his victim and that the offender suffers from a severe psychotic disorder.

A repulsive incident, such as the murder in the playground, is incomprehensible. What drives a person to kill an unknown man in front of small children? The news that came out several months later was hardly astounding: according to a psychiatric assessment the offender was regarded as not criminally responsible for his act because of a severe psychotic disorder. These types of incidents, which are bizarre and brutal at the same time, are reported in the national, or even the international media. In the summer of 2008, the news that a passenger of a Greyhound bus in Winnipeg decapitated and mutilated his sleeping seatmate with a Rambo knife made headlines across the world. With these types of incidents, which are regarded as extreme but also as exceptional, it is clear that criminal justice, as well as mental health, are involved.

Extreme offenses, as described above, are only the tip of the iceberg of all the situations in which criminal justice and mental health operate jointly. When following local news items, there appear to be many public order issues, such as the confused man on the Dam-square, where mental health professionals and police are both involved. However, also out of the sight of the public eye, there are many situations where mental health care and criminal justice, or more specifically mental health workers and police officers, work together.

A police officer knows where psychiatric patients in his area live who tend to avoid health care and cause problems in the neighborhood, at which addresses domestic violence regularly takes place and where forensic outpatients and rehabilitating former prisoners - also those who have committed sexual offenses in the past-live. Psychiatrists are regularly called for help with detainees who seem to have severe mental problems. In the daily practice of psychiatric institutions, health care workers encounter a lot of violence [40] and the police are often asked to offer assistance. According to a Dutch national study, police officers estimate that on average they spend $13 \%$ of their entire working hours on activities related to confused persons [2]. The researchers note that there is a lack of reliable data on this topic, and they conclude that dealing with confused persons is an important part of the police officer's tasks.

When considering all situations where both criminal justice as well as mental health are involved, there appears to be a frequent and sometimes intensive collaboration between both parties, in order to prevent crime and uphold justice. This paper addresses this cooperation and these activities on the boundary between psychiatry and criminal law that keeps the city livable and prevents a large amount of crime and nuisance. It does not pretend to give an overview of all projects and programs where mental health, as well as criminal justice, are involved, but purports to shed light on this cooperation. Firstly, the literature on the relationship between mental disorders and criminal behavior is examined and the cooperation between the mental health care system and the criminal justice system is described more closely. After that, possible pitfalls are presented that seem to threaten a successful cooperation. Subsequently, these pitfalls are illustrated by two examples of collaboration. 


\section{Mental disorders and criminal behavior}

Although police officers regularly encounter mentally disturbed persons, psychiatric disorders, like bipolar disorder, major depression, schizophrenia and other psychotic disorders [3], are seldom put forward in criminological theories as an explanatory factor for criminal behavior [29, 32]. In fact, criminal behavior by psychiatric patients has mainly been studied in forensic psychiatry. Although these mainly descriptive studies provide little information about the causality of this relation [21], there appears to be a significant association between severe mental disorders and criminal behavior.

Studies on the mental health of prisoners reveal a high prevalence of mental illnesses. According to a systematic review of surveys on psychiatric disorders in general prison populations, about one in seven prisoners in western countries is diagnosed with psychotic illnesses or major depression [12]. According to Torrey et al. [37] at least $16 \%$ of inmates in jails and prisons in the USA have a serious mental illness; they state that there are three times more seriously mentally ill persons in jails and prisons than in hospitals.

The association between mental disorders and criminal behavior could also be investigated by examining rates of offending among persons suffering from mental disorders. However, Hodgins [19] and Van Leeuwen and Harte [39] state that judicial authorities tend to dismiss criminal acts committed by psychiatric patients, especially if these patients receive psychiatric treatment within a closed setting. Therefore, it can be assumed that the dark number in studies focusing on psychiatric populations is substantial.

In fact, confining the examination to populations of psychiatric patients or prisoners implicates a selection that might strongly bias the results, since patients who are hospitalized or imprisoned may be different from those who are not. This objection partly applies to the study of Wallace, Mullen and Burgess [41], who linked a psychiatric case register to the records of convictions of offenses. Their results showed that patients who had prior contact with psychiatric services because of schizophrenia demonstrated a tenfold likelihood to commit homicide. An increased likelihood of homicide in subjects with major mental disorders was also demonstrated by Schanda et al. [30]. The soundest design for the examination of the risk of criminal behavior associated with mental disorders is the cohort study in which violence is measured after a diagnosis is made. In the studies of Wallace, Mullen and Burgess [41] and Fazel et al. [10] a cohort of psychiatric patients was examined. Tiihonen et al. [36] studied prospectively an unselected 1966 birth cohort $(N=12,058)$ in Northern Finland until the end of 1992. These studies indicate that the risk of criminal behavior was significantly higher among subjects with psychotic disorders, especially for persons suffering from schizophrenia with coexisting substance abuse.

The exact extent and nature of the relationship between psychiatric disorders and criminal behavior and the mediating role of substance abuse is not yet fully understood $[10,11,21,43]$. However, despite several methodological limitations, a large number of studies reveal a positive and statistically robust association between major mental illnesses and violent behavior. 


\section{Collaboration in practice}

The criminal justice system deals for a substantial part with mentally disturbed persons. The mental health care system is often called to assess and care for persons under arrest. Public prosecutors and judges frequently encounter suspects who seem to suffer from a mental disorder. In the United States courts require that defendants are competent to stand trial, which means that defendants cannot be prosecuted if they suffer from a mental disorder that prevents them from understanding the proceedings and that also prevents them from assisting in the preparation of their defense. Based on a defendant's unusual behavior, a judge, prosecutor, or defense attorney may ask if a trial can be postponed until the defendant has been examined, and his or her ability to understand the proceedings has been determined in a court hearing. If a judge finds that a defendant doesn't understand what's going on, the defendant will probably be placed in a mental institution until competence is reestablished. The number of inquiries throughout the Unites States is approximately 60,000 each year [28].

In many European countries a substantial part of the convicts for severe offenses suffering from a serious mental illness stay in specialized forensic psychiatric hospitals [6]. In the Netherlands, the criminal court can impose forensic psychiatric treatment in a medium or high-security hospital on offenders of severe violent crimes suffering from a mental disorder and who also pose a serious risk to society because of this disorder. In less severe cases, the judge frequently utilizes the possibility to impose ambulant psychiatric treatment using suspended sentences with special conditions, in order to diminish the risk of recidivism [1]. Most former forensic psychiatric patients receive care and supervision in general psychiatric services. In prison, detainees suffering from severe mental disturbances often receive mental health care; in some countries the prison system includes special care units.

To a large extent, the joint care of mentally disturbed persons takes place in society and is aimed at the prevention of nuisance, dangerous situations and criminal acts [20]. As described above, police officers on the street regularly have to deal with civilians who cause inconvenience or even insecurity. Patients suffering from severe mental disorders often have impaired insight into their situation and disease and, as a consequence, tend to avoid care and refuse to take medication. Moreover, psychiatric patients who behave aggressively have an increased risk of not receiving the necessary treatment. In most cases, the police officer is the first contact of these patients if the situation escalates.

\section{Possible pitfalls}

In practice, the criminal law system deals for a substantial part with persons suffering from psychopathology, whereas mental health workers encounter a considerable amount of violence while providing care. Examining the situations where the criminal justice system and mental health institutes are jointly involved to prevent crime, some pitfalls emerge that seem to threaten a successful cooperation. Firstly, there seem to be unrealistic expectations of the effect of mental health treatment. Secondly, the possibility to predict future criminal behavior is overestimated. Finally, both involved parties work from a fundamentally different perspective and pursue different goals: providing care versus reducing crime. 


\section{Unrealistic expectations of treatability}

Despite significant improvements in the last decennia, psychiatric disorders are hard to treat and most disorders are regarded as chronic lifelong diseases. The symptoms of major psychiatric disorders, like schizophrenia, can often be reduced by means of cognitive behavior therapy [44] and medication [23]. However, the motivation of patients to participate in therapy and take medication is often absent since there are serious side effects, and patients often lack insight into their own illness [31]. Furthermore, the treatment of addiction problems and personality disorders, like the antisocial personality disorder or the borderline personality disorder, is regarded as extremely difficult $[7,22,27]$. How realistic is it to assume that high reoffending rates can be reduced significantly by the psychiatric treatment of offenders very often suffering from multiple disorders, and a criminal history with severe violent crimes? In fact, it isn't.

In the context of treatment in criminal justice, the expectations of the treatability seem to be very high. Although the recidivism rates after imprisonment, in general, are high, it is demanded that former forensic patients return into society without any risk. Care providers are held responsible for any relapse or, even worse, any new criminal act. Policy makers, as well as the judiciary, appear to have high expectations towards the preventive effect of mental health treatment that responds to the criminogenic needs of the offender. These expectations are also reflected by the installation of accreditation committees in many countries that have the task to establish a limited range of judicial behavioral interventions which have proven to be effective in reducing recidivism (see for example: crimesolutions.gov).

\section{Overestimation of the possibility to predict criminal behavior}

Apart from the expectation that it is possible to reduce the risk of recidivism of offenders with a mental illness significantly by means of psychiatric treatment, there also seems to be a strong confidence in the mental health workers' capacity to predict recidivism on an individual level and to accurately identify those individuals who are a risk to society. What do we know about the false negatives (patients who are dangerous but are not assessed as being a risk) and the false positives (patients who are in fact not dangerous but are assessed as being a serious threat and are monitored intensively, even though this is not strictly necessary)? In other words, what is the predictive validity of risk assessments?

Research has shown that judgments by clinicians are flawed. Like all human beings, clinicians tend to seek for confirmation of their preliminary, subjective ideas, a phenomenon known as confirmation bias [9]. Moreover, people perceive incorrect relationships between the characteristics of persons and tend to overestimate the quality of their judgments. Hence, in the past decades, research in forensic psychiatry has largely focused on the development of instruments for risk assessment. These instruments are not based on some theory on the relationship between disorders and criminal behavior but are a compilation of characteristics of offenders that are assumed to be related to the risk of re-offending. Many instruments have been developed in the past years, such as the HCR-20 V3 [8] and the STATIC-99 [14] for predicting violence, and the SVR-20 [5] for predicting the risk of sexual violence. Risk assessments are assumed to provide a more objective and valid estimation of an offender's risk to society. Therefore, these 
instruments are a structural (and often obligatory) part of forensic psychiatric and psychological assessments that support the decision to impose or end a measure or to provide permission for trial leave.

The predictive validity of risk assessment instruments can be empirically examined by comparing risk assessments with actual recidivism rates. Several authors warn that the predictive validity of risk assessment instruments is mediocre or even insufficient $[15,16]$ and that these instruments are not able to provide valid predictions on an individual level. This view was confirmed by the results of a meta-analysis [13], using 73 databases from 13 countries containing data on risk assessments and recidivism of 24,827 offenders. These meta-analyses also revealed that the chance for a false positive decision is substantial when using a risk assessment instrument. In conclusion, the possibility to predict recidivism on individual level is limited, also if risk assessment instruments are used.

\section{Different perspectives and different goals}

At first glance, the idea of parties collaborating in the supervision of a patient seems beneficial. Combining the knowledge and expertise from different backgrounds broadens the scope and results in more manpower. Consulting the literature on cooperation $[4,34,35]$ reveals that cooperation can indeed be beneficial if a number of conditions are met, such as good information transfer, clear division of tasks, joint vision and equal participation [17]. Moreover, a fruitful cooperation seems to be strongly dependent on the individuals involved and diverging opinions between parties may create difficulties.

In this respect, cooperation between the mental health profession and the criminal justice system seems to be vulnerable. For mental health care workers, providing medical information is subject to boundaries, both legally and professionally [25]. Firstly, the information that care workers are supposed to share with police officers may be subject to professional medical confidentiality. Moreover, it is questionable whether all parties involved possess sufficient knowledge of the boundaries that psychiatrists and other practitioners are subject to and the circumstances under which professional confidentiality can be breached. Hesitance from care providers to share information might result in mutual incomprehension and have a negative effect on collaboration.

Another vulnerable fact is that both parties pursue different goals. Mental health workers provide care and strive after the improvement of the patient's health and wellbeing. The criminal justice system focusses on another objective: maintaining the security of the society. Within this context, the interest of individual patients is of secondary importance. Both parties should restrict themselves to their expertise. A police officer is not a clinician, and a person who is causing nuisance and is in need of care should be handed over to mental health care as soon as possible. Psychiatric behavior might otherwise be criminalized, and patients might get traumatized further. At the same time, a mental health worker is not a detective; working too closely with the criminal justice system might disrupt the confidentially of the relationship with the patient and impede treatment.

Another complication stems from the already mentioned high expectations regarding the treatability and predictability of criminal behavior caused by mental disorders. These unrealistic expectations will never be met in practice, and even if all precautions 
are taken, serious incidents may occur. Especially in cases where innocent civilians are victimized, outrage in society and turmoil in politics may further amplify discontent, which is likely to put the collaboration between the involved parties under increasing pressure.

\section{Two case studies}

The vulnerability of cooperation between the criminal justice and the mental health system is illustrated by two case studies from The Netherlands: the pilot Threat Management and the detention under a hospital order.

\section{The pilot Threat Management}

On Queen's Day, 30th of April 2009, while the Dutch Royal family goes on a tour in an open bus through the city of Apeldoorn, a private car drives through a crowd of people with an extremely high speed, knocking over crush barriers, and crashing into a statue. Many people get injured, and eight people die, including the driver himself. Although the motives of the driver never became clear, this incident seems to be an assault on the Royal Family by a mentally disturbed man.

In the subsequent years, several official occasions, where the Royal family is present, are disrupted by psychiatrically disturbed persons. For example, in September 2010 a man throws a tea light holder and hits the Queen's coach. Psychiatric assessment reveals that the man suffers from a delusional disorder and that his delusions are related to the Royal Family. With the prospect, at that moment, of the Succession to the throne by the crown prince - a major ceremony that was to be attended by hundreds of thousands of citizens as well as dignitaries and press from all over the world, and that took place in Amsterdam in April 2013 - these incidents were a major concern.

Within this context, the pilot Threat Management was developed and launched in 2010 [25]. The aim of this program is to identify individuals that threaten Dutch celebrities and to eliminate their threats by means of a person-oriented approach. In this approach, mental health institutes and regional and national police are the main collaborating parties. The pilot phase concentrates on threats against members of the Royal Family and the Prime Minister. The intention is to expand the scope of the pilot over time to threateners of other national celebrities holding a public position. In an exante evaluation of the pilot [25] the researchers warn for insufficient clarity among the involved parties on the definition of threateners. Another main concern is the lack of a reliable and valid risk assessment instrument to identify and monitor this specific highrisk group.

Early April 2013, about 2 weeks before the Succession, Dutch newspapers report about the pilot, at that moment, about a hundred threateners are being monitored. Later on, the results of a process evaluation of the pilot are published [26]. According to this evaluation report, the target group consists of 136 persons; 13 of them are regarded as being a serious threat to society. These 13 persons are being monitored intensively by repeated risk appraisals. It is unclear on what grounds individuals have been selected for the target group and the high-risk group. The researchers question whether the energy and capacity are spent on those individuals who pose the greatest threat to society. 


\section{Duration of the detention under a hospital order}

If an offender commits a serious violent crime and, according to a psychiatric assessment, the offender is considered not responsible or diminished responsible because of a psychiatric disorder and there is a substantial risk of re-offending because of this psychiatric disorder, the judge in the Netherlands has the possibility to enforce the detention under a hospital order (in Dutch called "terbeschikkingstelling"). The aim of this measure is twofold: protecting the society and enabling a safe re-socialization into society. The offender is treated in a specialized high-security hospital. In the Netherlands, about 1800 persons are being treated under the terms of this order [38].

An essential element of this treatment is trial leave. Being on trial leave, the patient practices skills that have been trained during the intramural treatment. Also during trial leave, the patient's potentials for a successful re-socialization are assessed and hospitalization of the patient, which has an adverse effect on the chance of a successful and safe return into society, is pushed back. There are several subsequent phases of trial leave. In the first phase small trips, like a 10 min walk, are made, guided by armed guards. During the last phase, the patient is living outside the hospital terrain and is supervised by the probation service. For every subsequent phase, a leave permission from the Ministry of Security and Justice is required, and every individual's leave permission is evaluated on a yearly basis.

In June 2005, a patient who is detained under a hospital order escapes during a guided leave, by running away at a crowded train station. For the first time in Dutch history, the police publish a wanted notice of the escaped patient in the Dutch media. If the man is arrested a few days later, it appears that he has killed an old man. Dutch society is deeply shocked and blames the hospital as well as the Minister of Security and Justice, who gave permission for this leave. During a debate in Parliament, the Minister promises to install a Parliamentary Inquiry Committee. The objective of this inquiry is to find out why the detention under a hospital order is no longer able to provide society with sufficient protection against incidents committed by current and former patients. This objective is remarkable in light of the fact that on a yearly basis in only $0.2 \%$ of the leaves patients do escape (using a very broad definition of escape by also including cases of returning to the clinic later than had been agreed on) and that on average these escapes result in one serious criminal act a year [18]. One of the parliamentary committee's pieces of advice is to install an extra advisory board, consisting of external forensic psychiatrists and psychologists, who review every individual decision on providing or extending a leave permission.

The commotion surrounding the detention under a hospital order results in a negative attitude of politicians as well as society in general towards this measure. The specialized hospitals are criticized for being too lenient and prevailing the needs of dangerous offenders above those of innocent citizens. Consequently, the hospitals become more reluctant in their applications for leave permissions. The 'outflow' of patients under a hospital order is further frustrated by the fact that the willingness of general mental healthcare institutions, which are supposed to treat and take care of former tbs patients, decreases dramatically. As a consequence, the duration of the treatment, which is often attached subsequently to a long prison sentence, rises from an average of 5 years in 1995 to an average of about 10 years 
in 2012 [24]. ${ }^{1}$ Although the objective of the measure is protecting the society as well as enabling a safe re-socialization into society, the emphasis has shifted entirely to the first aim.

In response to this growing duration of the treatment, suspects of severe violent crimes increasingly refuse to cooperate in an assessment of possible mental faculties. Without such a psychiatric assessment, the court in principle has to hold a refusing suspect as fully responsible, since no mental disorder can be established and there is no possibility to demonstrate that there is a pathologically-based risk of re-offending. Judges also seem to become more reluctant to impose the tbs measure, as in many cases, the duration of confinement seems to be disproportionate to the seriousness of the offense. As a result, the 'inflow' of new patients decreases [38]. This might implicate that offenders who are a danger to society because of a psychiatric disorder return to society after serving the prison sentence without receiving any treatment.

The Ministry of Security and Justice acknowledges these problems and new policies to curb the increasing duration of the tbs treatment are being explored. To be able to examine and compare the performance of individual hospitals, a feasibility study is executed to find out whether parameters of quality can be achieved by differentiating between recidivism rates on hospital level [42]. The researchers conclude that the number of reconvictions is too small to determine variation in their performance on a statistical basis. Furthermore, a working group has been installed to investigate how the duration can be pushed back [33]. Together with their recommendations to promote inflow and outflow of patients, this group concludes that the evident quality and efficacy of the tbs measure seems to be undervalued by the public as well as by stakeholders.

\section{Conclusion and discussion}

Although psychiatric disorders do not have a central position in many criminological theories, there seems to be an evident relationship between psychiatric disorders and criminal behavior. This relationship is particularly evident in extreme aggressive acts committed by mentally disturbed offenders evoking repugnance and being extensively reported in de media. But also in daily life, law enforcement officials regularly deal with people who are, to a certain extent, mentally disturbed. As a result, on a local level, there are many types of cooperation that prevent a large amount of crime and nuisance and keeps the city livable.

Psychiatric patients who commit crimes should not be regarded as a distinguished group of offenders. In the general population the prevalence of psychiatric disorders, mild or very severe, is high. This is especially true for those who come into contact with the criminal justice system. At the same time, prevalent mental disorders do not always (completely) underlie and explain aggressive or criminal acts committed by psychiatric patients. It is often suggested that psychiatric patients do not belong in the criminal system since they are not responsible for their acts and are just in need of care. However, most mentally ill offenders are at least to some extent responsible for their

\footnotetext{
${ }^{1}$ Using an alternative method of estimation, Van Gemmert \& Van Schijndel (2014) recently presented somewhat more optimistic results and a modest decrease in the duration.
} 
acts and in most cases it is not possible to categorize mentally disordered offenders exclusively as bad or mad. This implies that monitoring, supervising and taking care of offenders who suffer from a mental disorder is a joint task of mental health and the criminal justice system.

Even though the examples of collaboration that have been examined more closely in this paper stem from The Netherlands, they illustrate some pitfalls that seem typical for the way Western societies in general deal with mentally disturbed patients who cause nuisance or commit crimes. It seems that the sometimes intense cooperation between criminal justice officers and mental health care workers is vulnerable. Mental health workers and law enforcement officers have different, sometimes conflicting goals, and they work from different perspectives. Whereas mental health workers provide care and primarily act for the benefit of the patient, police officers as well as politicians and policy makers mainly strive for safety in society. On top of that, there are unrealistic expectations regarding the possibility to predict which mentally ill offender is likely to re-offend and to regard the possibility to reduce the risk of re-offending significantly by means of psychiatric treatment. It is demanded that patients that are treated in a judicial context return into society without any risk, and that this safe return should be accomplished within a restricted time span. This can only be achieved if it is possible to predict who is a public threat and who is not. However, the predictive validity of risk assessment instruments seems to be flawed. An extra complication is the social and political indignation if, in spite of all precautions and efforts, a severe incident takes place. The subsequent discontent in society puts extra pressure on the cooperation.

It should be clear that there are significant differences between societies concerning the access to psychiatric treatment and the availability of appropriate programs for psychiatric patients, who often have low insight, tend to avoid care and show aggressive behavior. However, in all situations, it is of major importance that the expectations regarding mental health care programs are reduced to a realistic level. In the past years, research in forensic psychiatry has mainly focused on the development of risk assessment instruments. Committees have been installed to achieve a repertoire of judicial interventions that have proven to be effective, in order to attain the situation that only evidence-based interventions are implied. However, both objectives seem to be utopian. Although ultimate efforts ought to be requested to protect society against mentally disturbed offenders, it should be acknowledged that these targets are not realistic. The mental health care profession can contribute significantly to a safer society but the possibilities are limited. Another misapprehension is that a sound and effective collaboration can be achieved by using more policy documents and work processes. However, Nelen et al. [25] warn that the emphasis on more protocols and red tape also has a downside. They argue that it might lead to social partners who only superficially comply with policies and are not actually committed. The result is that collaborations are officially established, but that partners are still working on cross-purposes, are insufficiently led by a common interest, and do not realize that they are interdependent for the success of the project.

Especially on a local level, parties seem to find each other, and new initiatives of cooperation arise and are further developed. These initiatives often strongly depend on the commitment and drive of the individual participants and the personal relationships that have been established with the patients and other partners. Such bottom-up initiatives might have more potential than top-down imposed programs or protocols. 
If not supported by the executors, top-down initiatives have the risk to become an empty formality.

Psychiatric pathology seems to be a topic that has in a way been neglected in criminology. The possible causal relationship between mental health disorders and aggressive and criminal behavior needs further examination as well as the supposed interaction with other factors like addiction problems, personality disorders and social problems such as homelessness. Only by obtaining this knowledge, substantial progress can be made in the prediction of reoffending and the treatment of mentally ill offenders. But apart from explaining criminal behavior, the way society and the criminal justice system deal with persons who are assumed to be a risk to society because of a mental disorder warrants examination from a criminological perspective.

Open Access This article is distributed under the terms of the Creative Commons Attribution 4.0 International License (http://creativecommons.org/licenses/by/4.0/), which permits unrestricted use, distribution, and reproduction in any medium, provided you give appropriate credit to the original author(s) and the source, provide a link to the Creative Commons license, and indicate if changes were made.

\section{References}

1. Aarten, P. G. M. (2014). Suspended sentences. Public opinion, compliance and recidivism. Academic Thesis. Amsterdam: Vrije Universiteit.

2. Abraham, M., \& Nauta, O. (2014). Politie en 'verwarde personen'. Onderzoek naar optreden van de politie in relatie tot personen met een verward gedrag. Amsterdam: DSP-group.

3. American Psychiatric Association. (2013). Diagnostic and statistical manual of mental disorders (5th ed.). Arlington, VA: American Psychiatric Publishing.

4. Ansell, C., \& Gash, A. (2007). Collaborative governance in theory and practice. Journal of Public Administration Research and Theory, 18(4), 543-571.

5. Boer, D. P., Wilson, R. J., Gauthier, C. M., \& Hart, S. D. (1997). Assessing risk for sexual violence: guidelines for clinical practice. In C. D. Webster \& M. A. Jackson (Eds.), Impulsivity: theory, assessment, and treatment (pp. 326-342). New York: Guilford.

6. de Kogel, C. H., \& Nagtegaal, M. H. (2006). Gewelds- en zedendelinquenten met een psychische stoornis. Wetgeving en praktijk in Engeland, Duitsland, Canada, Zweden en België. Den Haag: Boom Juridische uitgevers.

7. Dennis, M. L., Scott, C. K., Funk, R., \& Foss, M. A. (2005). The duration and correlates of addiction and treatment careers. Journal of Substance Abuse Treatment, 28(2), S51-S62.

8. Douglas, K. S., Hart, S. D., Webster, C. D., \& Belfrage, H. (2013). HCR-20 V3: assessing risk of violence - user guide. Burnaby: Mental Health, Law, and Policy Institute, Simon Frazer University.

9. Evans, J. S. B. T. (1989). Bias in human reasoning: causes and consequences. London: Erlbaum.

10. Fazel, S., Grann, M., Carlström, E., Lichtenstein, P., \& Långström, N. (2009). Risk factors for violent crime in schizophrenia. A national cohort study of 13,806 patients. Journal of Clinical Psychiatry, 70(3), 362-369.

11. Fazel, S., Gulati, G., Linsell, L., Geddes, J. R., \& Grann, M. (2009). Schizophrenia and violence: systematic review and meta-analysis. PLoS Medicine, 6(8), 1-14.

12. Fazel, S., \& Seewald, K. (2012). Severe mental illness in 33,588 prisoners worldwide: systematic review and meta-regression analysis. The British Journal of Psychiatry, 200(5), 364-373.

13. Fazel, S., Singh, J. P., Doll, H., \& Grann, M. (2012). Use of risk assessment instruments to predict violence and antisocial behavior in 73 samples involving 24827 people: systematic review and metaanalysis. British Medical Journal, 345, e4692. doi:10.1136/bmj.e4692.

14. Hanson, R. K., \& Thornton, D. (2000). Improving risk assessments for sex offenders: a comparison of three actuarial scales. Law and Human Behavior, 24(1), 119-136. doi:10.1023/A:1005482921333.

15. Hart, S. D., Michie, C., \& Cooke, D. J. (2007). Precision of actuarial risk assessment instruments. Evaluating the 'margins of error' of group v. Individual predictions of violence. British Journal of Psychiatry, 190 (suppl. 49), s60-s65. 
16. Harte, J. M., \& Breukink, M. D. (2010). Objectiviteit of schijnzekerheid? kwaliteit, mogelijkheden en beperkingen van instrumenten voor risicotaxatie. Tijdschrift voor Criminologie, 52(1), 52-72.

17. Harte, J. M., van Kalmthout, W. D., \& Knüppe, J. J. M. C. (2010). Forensisch psychiatrisch toezicht; evaluatie van de testfase van een vernieuwde vorm van toezicht op tbs-gestelden. Reeks criminologie nummer 7. Amsterdam: VU, Criminologie.

18. Hildebrand, M., Spreen, M., Schönberger, H. J. M., Augustinus, F., \& Hesper, B. L. (2006). Onttrekkingen tijdens verlof, ontvluchtingen en recidive tijdens de tbs-behandeling in de jaren 2000-2005. Utrecht: Expertisecentrum Forensische Psychiatrie.

19. Hodgins, S. (2008). Violent behavior among people with schizophrenia: a framework for investigations of causes, and effective treatment, and prevention. Philosophical Transactions of the Royal Society of London, Series B, 363, 2505-2518.

20. Lamberti, J. S., Weisman, R., \& Faden, D. I. (2004). Forensic assertive community treatment: preventing incarceration of adults with severe mental illness. Psychiatric Services, 55(11), 1285-1293.

21. Lamsma, J., \& Harte, J. M. (2015). Violence in psychosis: conceptualizing its causal relationship with risk factors. Aggression and Violent Behavior, 24, 75-82. doi:10.1016/j.avb2015.05.003.

22. Leichsenring, F., Rabung, S., \& Leibing, E. (2005). The efficacy of short-term psychodynamic psychotherapy in specific psychiatric disorders: a meta-analysis. Archives of General Psychiatry, 61, 1208-1216.

23. Lieberman, J. A., Stroup, T. S., McEvoy, J. P., Schwartz, M. S., Rosenheck, R. A., Perkins, D. O., Keefe, R. S., Davis, S. M., Dacis, C. E., Lebowitz, B. D., Severe, J., \& Hsiao, J. K. (2005). Effectiveness of antipsychotic drugs in patients with chronic schizophrenia. The New England Journal of Medicine, 353(12), 1209-1223.

24. Nagtegaal, M. H., van der Horst, R. P., \& Schönberger, H. J. M. (2011). Inzicht in de verblijfsduur van tbsgestelden. Cijfers en mogelijke verklaringen. Den Haag: Boom Juridische uitgevers.

25. Nelen, H., Leeuw, B., Bakker, F., \& Herrenberg, T. (2012). In de war en uit de bocht. Ex ante evaluatie van de aanpak van solistische dreigers binnen de pilot Dreigingsmanagement. Den Haag: Boom Lemma uitgevers.

26. Nelen, H., Mol, M., Plaisier, J., \& Peters, M. (2013). Pilot Dreigingsmanagement. De implementatie en wijze van uitvoering onder de loep. Maastricht: Universiteit Maastricht.

27. Perry, J. C., Banon, E., \& Ianni, F. (1999). Effectiveness of psychotherapy for personality disorders. American Journal of Psychiatry, 156(9), 1312-1321.

28. Pirelli, G., Gottdiener, W. H., \& Zapf, P. A. (2011). A meta-analytic review of competency to stand trial research. Psychology, Public Policy, and Law, 17(1), 1-53.

29. Sampson, R. J., \& Laub, J. H. (2005). A life-course view of the development of crime. The Annals of the American Academy of Political and Social Science, 602(1), 12-45.

30. Schanda, H., Knecht, G., Schreinzer, D., Stompe, T., Ortwein-Swoboda, G., \& Waldboer, T. (2004). Homicide and major mental disorders: a 25 years study. Acta Psychiatrica Scandinavica, 110(2), 98-107.

31. Schwartz, M. S., Swanson, J. W., Hiday, V. A., Borum, R., Wagner, R., \& Burns, B. J. (1998). Taking the wrong drugs: the role of substance abuse and medication noncompliance in violence among severely mentally ill individuals. Social Psychiatry and Psychiatric Epidemiology, 33(Suppl 1), S75-S80.

32. Siennick, S., \& Osgood, D. W. (2008). A review of research on the impact on crime of transitions to adult roles. In A. M. Liberman (Ed.), The long view of crime: a synthesis of longitudinal research (pp. 161187). New York: Springer.

33. Taskforce behandelduur tbs (2014). Rapportage taskforce behandelduur tbs. Bevindingen en aanbevelingen. https://www.rijksoverheid.nl/documenten/rapporten/2015/01/13/tk-bijlage-taskforcebehandelduur-tbs. Accessed 10 Jan 2015.

34. Terpstra, J. (2001). Netwerken en samenwerking bij de uitvoering van beleid. Beleidswetenschap, 15(2), 141-168.

35. Terpstra, J., \& Bakker, I. (2002). Met recht lokaal. Evaluatie van Justitie in de Buurt. Enschede: IPIT.

36. Tiihonen, J., Isohanni, M., Räsänen, P., Koiranen, M., \& Moring, J. (1997). Specific major mental disorders and criminality. A 26 years prospective study of the 1966 Northern Finland birth cohort. The American Journal of Psychiatry, 154(6), 840-845.

37. Torrey, E. F., Kennard, A. D., Eslinger, D., Lamb, R., and Pavle, J. (2010). More mentally ill persons are in jails and prisons than hospitals: A survey of the states (Research Report). http://www. treatmentadvocacycenter.org/storage/tac/documents/final_jails_v_hospitals_study.pdf. Accessed 5 Nov 2014.

38. van Gemmert, N., \& van Schijndel, C. (2014). Forensische Zorg in getal. 2009-2013. Den Haag: DJI.

39. van Leeuwen, M. E., \& Harte, J. M. (2011). Violence against care workers in psychiatry; is prosecution justified? International Journal of Law and Psychiatry, 34(5), 317-323. 
40. van Leeuwen, M. E., \& Harte, J. M. (2015). Violence against mental health care professionals: prevalence, nature and consequences. The Journal of Forensic Psychiatry and Psychology. doi:10.1080/14789949. 2015.1012533. 1-18.

41. Wallace, C., Mullen, P. E., \& Burgess, P. (2004). Criminal offending in schizophrenia over a 25 years period marked by deinstitutionalization and increasing prevalence of comorbid substance use disorders. The American Journal of Psychiatry, 161(4), 716-727.

42. Wartna, B. S. J., Bregman, I. M., Schapers, C. E., Blom, M., \& Boonmann, C. (2014). Recidivecijfers per fpc. Eindrapport van het haalbaarheidsonderzoek naar het gebruik van recidivecijfers op het niveau van de afzonderlijke tbs-instellingen. Den Haag: WODC.

43. Witt, K., van Dorn, R. A., \& Fazel, S. (2013). Risk factors for violence in psychosis. Systematic review and meta-regression analysis of 110 studies. PLOS ONE, 8(2), 1-15.

44. Zimmerman, G., Favrod, J., Trieu, V. H., \& Pomini, V. (2005). The effect of cognitive behavioral treatment on the positive symptoms of schizophrenia spectrum disorders: a meta-analysis. Schizophrenia Research, 77(1), 1-9. 